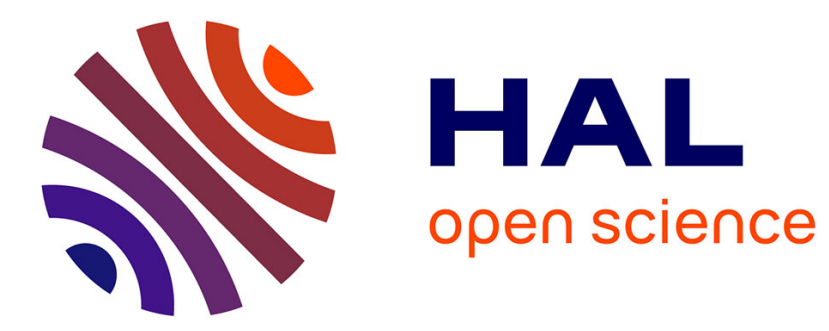

\title{
Pb0.8Sn0.2Te Infrared photodiodes by indium implantation
}

\author{
Th. Jakobus, W. Rothemund, A. Hurrle, J. Baars
}

\section{To cite this version:}

Th. Jakobus, W. Rothemund, A. Hurrle, J. Baars. Pb0.8Sn0.2Te Infrared photodiodes by indium implantation. Revue de Physique Appliquée, 1978, 13 (12), pp.753-756. 10.1051/rphysap:019780013012075300 . jpa-00244540

HAL Id: jpa-00244540

https://hal.science/jpa-00244540

Submitted on 1 Jan 1978

HAL is a multi-disciplinary open access archive for the deposit and dissemination of scientific research documents, whether they are published or not. The documents may come from teaching and research institutions in France or abroad, or from public or private research centers.
L'archive ouverte pluridisciplinaire HAL, est destinée au dépôt et à la diffusion de documents scientifiques de niveau recherche, publiés ou non, émanant des établissements d'enseignement et de recherche français ou étrangers, des laboratoires publics ou privés. 


\title{
$\mathrm{Pb}_{0.8} \mathrm{Sn}_{0.2}$ Te INFRARED PHOTODIODES BY INDIUM IMPLANTATION
}

\author{
Th. JAKOBUS, W. ROTHEMUND, A. HURRLE and J. BAARS \\ Institut für Angewandte Festkörperphysik der Fraunhofer-Gesellschaft, \\ D. 7800 Freiburg, Fed. Rep. Germany
}

\begin{abstract}
Résumé. - Des ions d'indium ont été implantés dans des films de $\mathrm{Pb}_{0,8} \mathrm{Sn}_{0,2}$ Te de type p pour produire des photodétecteurs à jonction $\mathrm{p}$-n à niveau peu profond. Les films ont été obtenus par épitaxie sur des plans de clivage (111) de $\mathrm{BaF}_{2}$ et ont montré des concentrations de trous de l'ordre de $10^{17} \mathrm{~cm}^{-3}$. L'implantation d'indium a été obtenue en utilisant des quantités comprises entre $2 \times 10^{13}$ $1 \times 10^{-15} \mathrm{~cm}^{-2}$ et une énergie de $700 \mathrm{keV}$, les films étant, soit à température ambiante, soit à $450 \mathrm{~K}$. Les profils de concentration d'indium ont été déterminés par SIMS avant et après recuit, des films implantés, à des températures atteignant $670 \mathrm{~K}$. Les films implantés étaient recouverts d'une couche de nitrure de silicium pour éviter l'évaporation pendant le recuit. Les propriétés électriques résultant de l'implantation d'indium ont été étudiées par des mesures de réflectivité en infrarouge lointain dans la région de résonance du plasma. Le type de porteur des couches implantées a été déterminé par la méthode thermoélectrique usuelle.

Pour changer les couches implantées en type $n$, les films ont dû être recuits à une température d'au moins $570 \mathrm{~K}$ pendant $30 \mathrm{~min}$. indépendamment de la quantité d'indium implantée.

Des diodes mésa ont été fabriquées par des procédés photoliphographiques habituels. On a obtenu des résistances surfaciques atteignant $0,4 \Omega \mathrm{cm}^{2}$.
\end{abstract}

\begin{abstract}
Indium ions were implanted in p-type $\mathrm{Pb}_{0.8} \mathrm{Sn}_{0.2} \mathrm{Te}$ films to produce shallow p-njunction infrared photodetectors. The films were grown epitaxially on $\mathrm{BaF}_{2}(111)$ cleavage planes and showed hole concentrations of the order of $10^{17} \mathrm{~cm}^{-3}$. The indium implantation was carried out using doses between $2 \times 10^{13}$ and $1 \times 10^{-15} \mathrm{~cm}^{-2}$ and an energy of $700 \mathrm{keV}$ with the films either at room temperature or $450 \mathrm{~K}$. The indium concentration profiles were determined by SIMS before and after annealing of the implanted films at temperatures up to $670 \mathrm{~K}$. The implanted films were covered with silicon nitride layers to avoid evaporation during the subsequent annealing. The electrical properties caused by the indium implantation were examined by far infrared reflectivity measurements in the plasma resonance region. The carrier type of the implanted layers was determined by a conventional thermoelectric method.

To convert the implanted layers into n-type the films had to be annealed at a temperature of at least $570 \mathrm{~K}$ for $30 \mathrm{~min}$. regardless of the implanted indium dose.

Mesa diode were fabricated by standard photolithographic procedures. Zero bias resistance area products as high as $0.4 \Omega \mathrm{cm}^{2}$ were obtained.
\end{abstract}

1. Introduction. - Implantation of $\mathrm{In}^{++}$ions has successfully been used to fabricate $p-n$ junction photodiodes in $\mathrm{PbTe}$. The results have been reported at the ESSDERC last year. In this study the effect of In implantation in thin films of p-type $\mathrm{Pb}_{0.8} \mathrm{Sn}_{0.2} \mathrm{Te}$ was investigated. The use of $\mathrm{In}^{++}$ion implantation to convert layers of $\mathrm{p}$-type $\mathrm{Pb}_{0.8} \mathrm{Sn}_{0.2} \mathrm{Te}$ into n-type material will be discussed and some results on infrared photovoltaic detectors for the 8 to $12 \mu \mathrm{m}$ region fabricated by this technique will be presented.

2. Experimental. - The $\mathrm{Pb}_{0.8} \mathrm{Sn}_{0.2} \mathrm{Te}$ films used for this investigation were grown on cleaved $\mathrm{BaF}_{2}$ substrates by evaporation in vacuo [1]. The crystallographic orientation of the films was checked by X-ray diffraction and was found to be in agreement with the (111) cleavage planes of the $\mathrm{BaF}_{2}$ substrate. The as-grown films are typically $5 \mu \mathrm{m}$ thick and exhibit hole concentrations of approximately $5 \times 10^{17} \mathrm{~cm}^{-3}$ with mobilities of the order of $10^{4} \mathrm{~cm}^{2} \mathrm{~V}^{-1} \mathrm{~s}^{-1}$ at the temperature of liquid nitrogen. The indium was doubly ionized and implanted with an energy of $700 \mathrm{keV}$. The implantation dose was varied between
$2 \times 10^{13}$ and $1 \times 10^{15} \mathrm{~cm}^{-2}$. During the implantation the film temperature was kept constant either at $300 \mathrm{~K}$ or $450 \mathrm{~K}$. In the previous studies of $\mathrm{In}^{++}$ implantation in p-type $\mathrm{PbTe}$ films, where the implantations were carried out with the films either at liquid nitrogen or room temperature, we have found a much larger radiation damage after implantation at $77 \mathrm{~K}$ than after implantation at $300 \mathrm{~K}$. This result indicates a considerable self-annealing of the radiation damage in $\mathrm{PbTe}$ even at room temperature. In order to keep the radiation damage as small as possible in the $\mathrm{Pb}_{0.8} \mathrm{Sn}_{0.2} \mathrm{Te}$ films implantations at $450 \mathrm{~K}$ were also performed this time. As will be seen later, the high temperature implantation turned out to be of no advantage. In any case a subsequent annealing at much higher temperatures was necessary to restore the damaged film regions effectively and to convert the implanted layers into n-type material.

To avoid evaporation during the annealing the film surfaces had to be protected. The first annealing experiment was performed with films which were coated with pyrolytic $\mathrm{SiO}_{2}$ at a temperature of $630 \mathrm{~K}$ for $5 \mathrm{~min}$. Using growth rates of about $300 \AA \mathrm{min} .^{-1}$ 
we produced $\mathrm{SiO}_{2}$ coatings typically $1500 \AA$ thick. For the protection of $\mathrm{PbTe}$ surfaces this procedure proved to be sufficient. The $\mathrm{Pb}_{0.8} \mathrm{Sn}_{0.2} \mathrm{Te}$ surfaces, however, became strongly p-type after coating with pyrolytic $\mathrm{SiO}_{2}$. Hole concentrations as high as $10^{19} \mathrm{~cm}^{-3}$ were determined from plasma resonance measurements at these surfaces. This finding can be explained by the formation of Sn-oxide in the beginning of the pyrolytic $\mathrm{SiO}_{2}$ coating in agreement with surface examinations of SnTe by ESCA. Further on, $\mathrm{RF}$-sputtered $\mathrm{Si}_{3} \mathrm{~N}_{4}$ therefore was used as protective coating for $\mathrm{Pb}_{0.8} \mathrm{Sn}_{0.2} \mathrm{Te}$. The results presented here refer to samples which were coated with approximately $1800 \AA$ of $\mathrm{Si}_{3} \mathrm{~N}_{4}$ by sputtering at room temperature before the heat treatments. The annealing was performed at various temperatures between $420 \mathrm{~K}$ and $670 \mathrm{~K}$.

Subsequently in some of the implanted and annealed samples the In concentration profile was determined by SIMS. To examine how implantation and annealing affects the electrical properties of $\mathrm{Pb}_{0.8} \mathrm{Sn}_{0.2} \mathrm{Te}$ the carrier concentration and the type of conductivity were analysed by far infrared reflectivity measurements and thermoelectric probing.

3. Results and discussion. - We shall discuss first the concentration and the distribution of the implanted indium which were determined by SIMS measurements. A typical In implantation profile in $\mathrm{Pb}_{0.8} \mathrm{Sn}_{0.2} \mathrm{Te}$ is shown in figure 1 . The In concentration was determined by measuring the ion current ratio of $\mathrm{In}^{+}$and $\mathrm{Te}^{+}$. For calibration In doped $\mathrm{PbTe}$ standards were used. In the table of figure 1 the measured In doses as determined by integration of the concentration profiles are given for some samples which were implanted and annealed at various temperatures. The integrated values of these samples which were implanted with $2 \times 10^{14} \mathrm{In}^{++}$ions $\mathrm{cm}^{-2}$ agree well with each other regardless of the implantation and annealing temperatures. From these results we can conclude that losses of In during the annealing up to temperatures of $620 \mathrm{~K}$ are negligible. The measured doses, however, are smaller by a factor

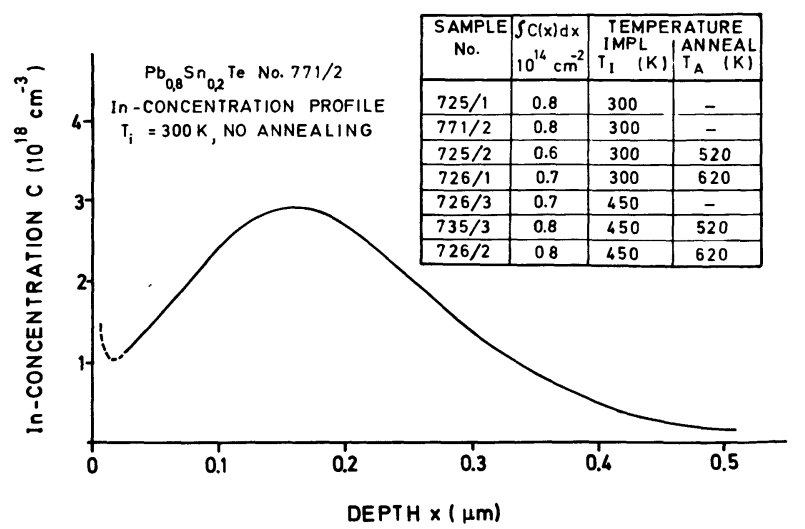

FIG. 1. - Indium concentration analysis by SIMS in $\mathrm{In}^{++}$implanted $\mathrm{Pb}_{0.8} \mathrm{Sn}_{0.2} \mathrm{Te}$ films (dose $2 \times 10^{14} \mathrm{~cm}^{-2}, 700 \mathrm{keV}$ ). Integrated values of the concentration profiles of films which were implanted and annealed at various temperatures are given in the table. of 2.7 on the average than the nominal implantation doses. So far we have no explanation for this discrepancy which also was found in the implantation studies of $\mathrm{PbTe}$.

In figure 2 the maximum indium concentration determined from the measured concentration profiles of some $\mathrm{PbTe}$ and $\mathrm{Pb}_{0.8} \mathrm{Sn}_{0.2} \mathrm{Te}$ samples is plotted versus the implantation dose. The In concentration of both the $\mathrm{PbTe}$ and the $\mathrm{Pb}_{0.8} \mathrm{Sn}_{0.2} \mathrm{Te}$ samples show the same linear dependence over the entire dose range.

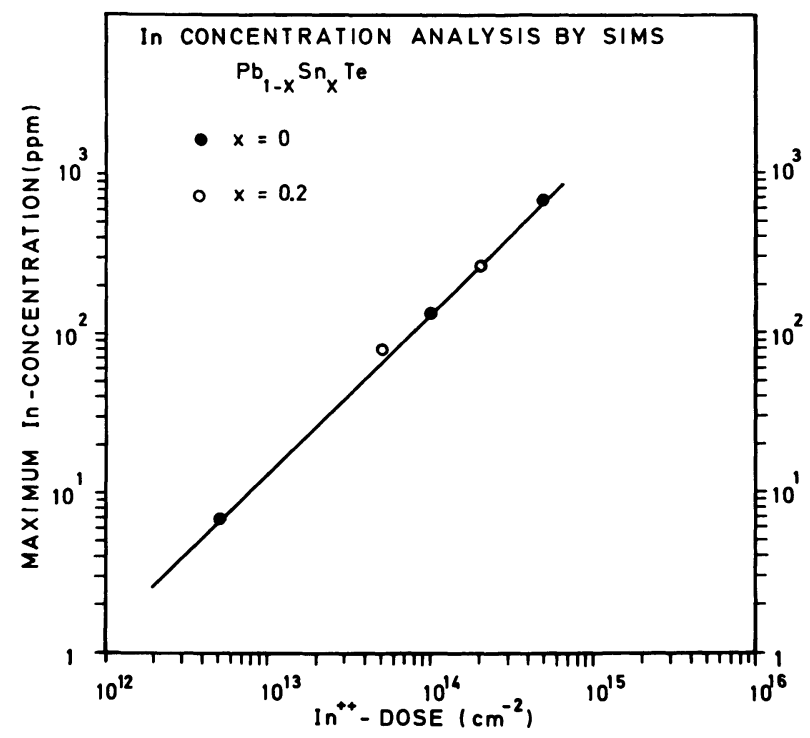

Fig. 2. - Maximum indium concentration determined from SIMS measurements versus $\mathrm{In}^{++}$implantation dose for various $\mathrm{PbTe}$ and $\mathrm{Pb}_{0.8} \mathrm{Sn}_{0.2} \mathrm{Te}$ films.

The influence of annealing on the In concentration profiles is presented in figure 3 . In spite of the marked scattering there are clear tendencies. At temperatures above $500 \mathrm{~K}$ a pronounced shift of the peak position towards the surface is accompanied by a decrease of the half width. At low temperatures the average of the measured peak positions corresponds to that which was calculated for a $700 \mathrm{keV}$ In implantation. In the high temperature region the measured peak positions equal approximately the calculated position of maximum damage. Thus a diffusion of In into the damaged surface region is likely to occur during the annealing at temperatures above $500 \mathrm{~K}$.

Next the doping effect of the implanted indium shall be discussed. To determine the charge carrier concentration the infrared reflectivity in the plasma resonance region of the $\mathrm{Pb}_{0.8} \mathrm{Sn}_{0.2} \mathrm{Te}$ films at room temperature was analysed. This is a handy and reliable method to measure the charge carrier concentration of implanted layers. The conduction type of the implanted layers was checked by the common thermoelectric hot point method with the films at liquid nitrogen temperature.

The results obtained for a $\mathrm{In}^{++}$dose of $2 \times 10^{14} \mathrm{~cm}^{-2}$ after the samples had been annealed 


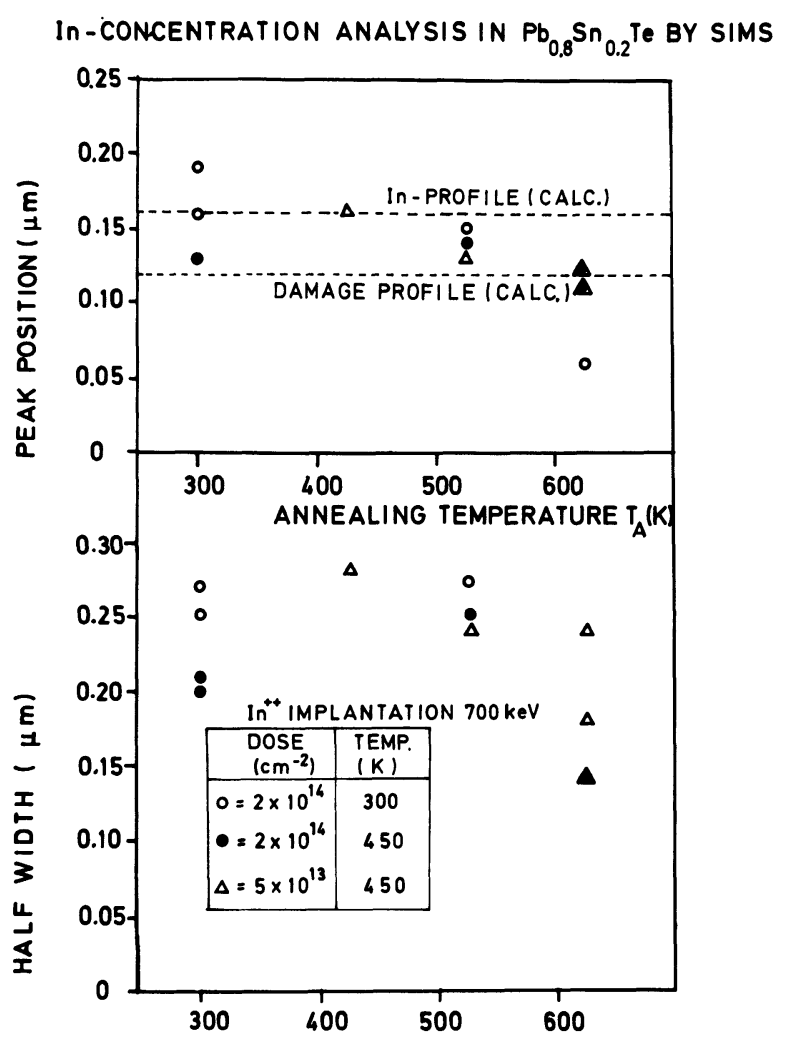

Fig. 3. - Peak position (upper half) and half width (lower half) of indium concentration profiles in $\mathrm{Pb}_{0.8} \mathrm{Sn}_{0.2} \mathrm{Te}$ films versus annealing temperature.

at various temperatures are presented in figure 4. For implantations at room temperature and subsequent annealing for $30 \mathrm{~min}$. at temperatures up to $520 \mathrm{~K}$ the implanted layers of the $\mathrm{Pb}_{0.8} \mathrm{Sn}_{0.2} \mathrm{Te}$ films remained $p$-type and exhibited almost the same carrier concentrations as before implantation.

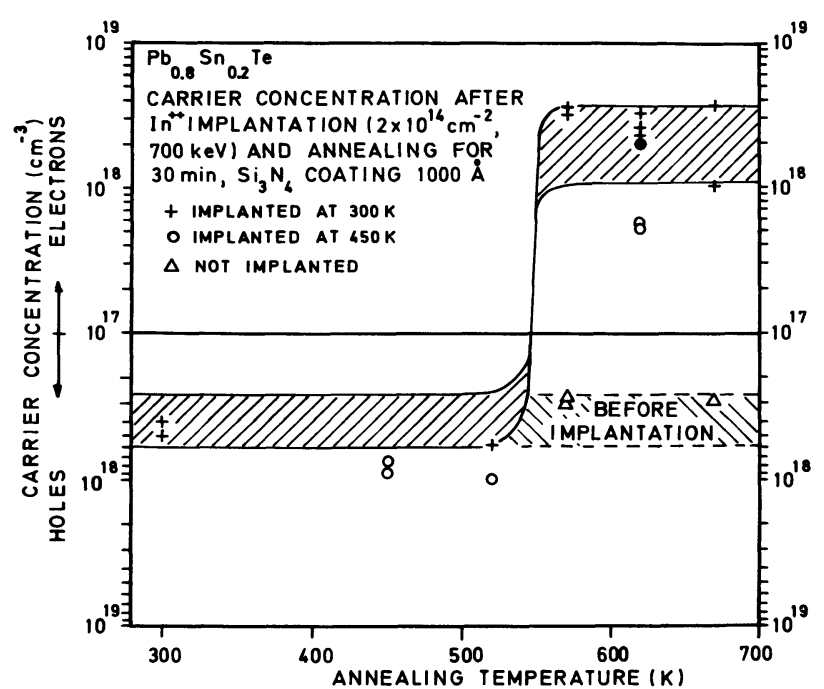

FIG. 4. - Carrier concentration of various $\mathrm{Pb}_{0.8} \mathrm{Sn}_{0.2} \mathrm{Te}$ films after $\mathrm{In}^{++}$implantation $\left(2 \times 10^{14} \mathrm{~cm}^{-2}, 700 \mathrm{keV}\right)$ and annealing for 30 min versus annealing temperature.

Somewhat higher hole concentrations were obtained in films which were implanted at $450 \mathrm{~K}$. This finding can be explained by vacuum annealing during the implantation at $450 \mathrm{~K}$ which results in a depletion of metal atoms in the surface region.

When the implanted films were annealed at $570 \mathrm{~K}$ or even at higher temperatures for $30 \mathrm{~min}$. the implanted layers were converted into n-type material with electron concentrations of the order of $10^{18} \mathrm{~cm}^{-3}$. For two of the films implanted at $450 \mathrm{~K}$ lower electron concentrations have been found which is probably due to the vacuum annealing effect just mentioned.

From these results we can conclude that the implanted In atoms are immobile and electrically inactive as long as the annealing temperature does not exceed $520 \mathrm{~K}$. At higher annealing temperatures the indium moves into the region of the radiation damage and becomes electrically active as a donor.

In this connection the dependence of the electron concentration on the $\mathrm{In}^{++}$dose is of interest. This is shown in figure 5. A large number of $p$ type $\mathrm{Pb}_{0.8} \mathrm{Sn}_{0.2} \mathrm{Te}$ films were implanted with various $\mathrm{In}^{++}$doses between $10^{13}$ and $10^{15} \mathrm{~cm}^{-2}$. Subsequently they were annealed for $30 \mathrm{~min}$ at temperatures equal to or above $570 \mathrm{~K}$. Irrespective of the experimental scattering the electron concentration in the implanted layers seems to follow the average In concentration up to an implantation dose of about $10^{14} \mathrm{~cm}^{-2}$ where the implanted layers exhibit electron concentrations of about $3 \times 10^{18} \mathrm{~cm}^{-3}$. Higher doses apparently do not produce higher electron concentrations. This saturation effect has also been found in $\mathrm{PbTe}$. The saturation level in $\mathrm{PbTe}$, however, is lower by a factor of 5 .

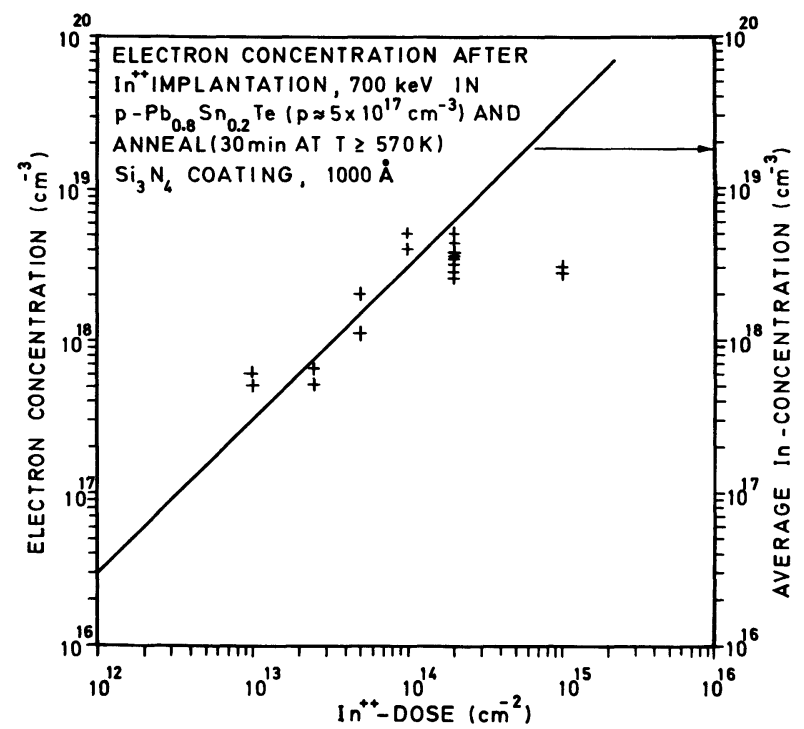

FIG. 5. - Variation of the electron concentration in $\mathrm{Pb}_{0.8} \mathrm{Sn}_{0.2} \mathrm{Te}$ films with $\mathrm{In}^{++}$implantation dose after annealing for $30 \mathrm{~min}$. at $T \geqslant 570 \mathrm{~K}$.

To gain a deeper insight into the doping mechanism additional experiments were performed with n-type $\mathrm{Pb}_{0.8} \mathrm{Sn}_{0.2}$ Te. The results are given in table $\mathrm{I}$. The electron concentration of various n-type samples was measured before and after implantation and anneal. For comparison two samples are included 


\section{TABLE I}

Electron concentration of $n-\mathrm{Pb}_{0.8} \mathrm{Sn}_{0.2}$ Te before and after $\mathrm{In}^{++}$implantation and anneal

$\begin{array}{ccccc}\text { Sample } & \begin{array}{c}\text { Before } \\ n\end{array} & \begin{array}{c}\text { Implantation } \\ \text { dose }\end{array} & \begin{array}{c}\text { Anneal } \\ T_{\mathrm{A}}(\mathrm{K})\end{array} & \begin{array}{c}\text { After } \\ n\end{array} \\ \text { No. } & 10^{18}\left(\mathrm{~cm}^{-3}\right) & 10^{14}\left(\mathrm{~cm}^{-2}\right) & 30 \mathrm{~min} . & 10^{18}\left(\mathrm{~cm}^{-3}\right) \\ 687 / 4 & 0.3 & 1 & 620 & 2 \\ 600 / 1 & 0.2 & 2 & 620 & 3 \\ 598 / 3 & 0.3 & 2 & 620 & 5 \\ 702 / 1 & 0.3 & 2 & 620 & 4 \\ 687 / 1 & 0.4 & 10 & 620 & 1 \\ 728 / 4 & 0.4 & - & 670 & 0.4 \\ 732 / 3 & 0.4 & - & 620 & 0.3\end{array}$

which were not implanted but annealed for $30 \mathrm{~min}$. As can be seen from the data the carrier concentrations of these two samples did not change significantly. The other samples, however, which were implanted with doses ranging from $10^{14}$ to $10^{15} \mathrm{~cm}^{-2}$ exhibited electron concentrations one order of magnitude higher than before the implantation and the anneal. The average equals $3 \times 10^{18} \mathrm{~cm}^{-3}$ and agrees with the saturation value found in the p-type samples after implantation.

This saturation effect is well known from numerous studies of the solid solution of InTe in $\mathrm{PbTe}$ and there are many speculations to explain this behaviour. Rosenberg and Wald [3] for example suggest an internal charge compensation by a vacancy-interstitial mechanism. Recently Averkin [4] and Borovikova [5] proposed a model of so called deep levels produced by replacement of $\mathrm{Pb}$ in In.

The results of the present investigations suggest that the implanted In combines with some charge compensating defect and annealing at temperatures above $520 \mathrm{~K}$ only offers a chance for In to replace metal atoms of the lattice and to become active as a donor. The cause of the saturation effect is still obscured.

Finally, diodes were defined by a photolithographic mesa etch technique which was originally developed for testing implanted $\mathrm{PbTe}$ diodes, where on the n-type mesa surfaces of the diodes thick In pads were evaporated and $15 \mu \mathrm{m}$ gold wires were attached by pressure bonding. Gold was evaporated on the p-type $\mathrm{PbTe}$ forming a framelike back-contact to the diodes. The same procedure was applied to implanted $\mathrm{Pb}_{0.8} \mathrm{Sn}_{0.2} \mathrm{Te}$ except for the bonding technique. By bonding the $\mathrm{Pb}_{0.8} \mathrm{Sn}_{0.2} \mathrm{Te}$ mesas directly on top of the In pads the diodes were destroyed presumedly by mechanical damage.

However, the current-voltage characteristics of the diodes could be measured at liquid nitrogen temperature by probing. An example of these measurements is presented in figure 6 . The $\mathrm{BaF}_{2}$ substrate was mounted on a cold finger made of copper. Therefore the measurements correspond to $0^{\circ} \mathrm{FOV}$. The resistance area product of the diode as determined from the $I-V$ curve at zero voltage amounts to approximately $0.4 \Omega \mathrm{cm}^{2}$. This value corresponds to a calculated detectivity of $4 \times 10^{10} \mathrm{~cm} \mathrm{~W}^{-1} \mathrm{~s}^{-1 / 2}$ at a wavelength of $10 \mu \mathrm{m}$.

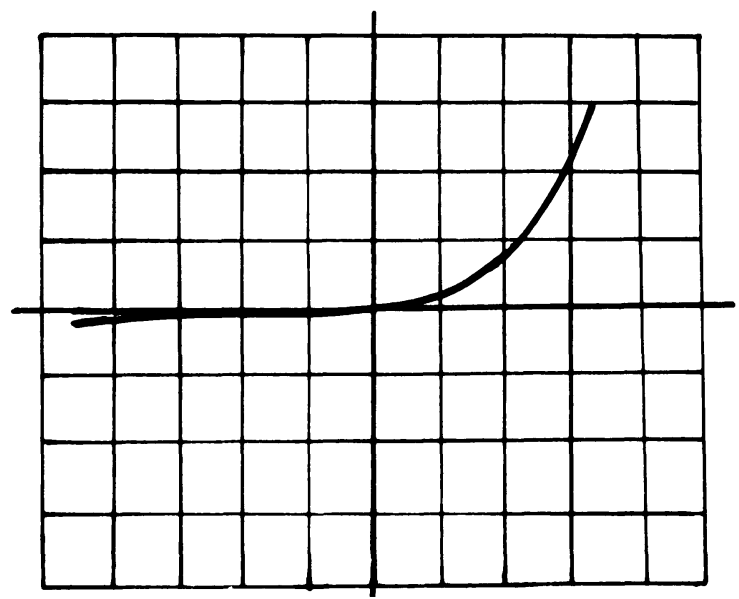

FIG. 6. - Current-voltage characteristic of an $\mathrm{In}^{++}$implanted $\mathrm{Pb}_{0.8} \mathrm{Sn}_{0.2} \mathrm{Te}$ diode No. 775/4-34 at $T=77 \mathrm{~K}$ and $0^{\circ}$ FOV. Diode area $A=4 \times 10^{-4} \mathrm{~cm}^{2}$. Vertical scale $100 \mu \mathrm{A} /$ div., horizontal scale $100 \mathrm{mV} /$ div.

4. Conclusion. - In conclusion, the present work demonstrates that In ion implantation in $\mathrm{Pb}_{0.8} \mathrm{Sn}_{0.2} \mathrm{Te}$ can be used to produce $p-n$ junctions. The implanted layers, however, have to be annealed at temperatures of at least $570 \mathrm{~K}$ for $30 \mathrm{~min}$. to convert the initially p-type material into n-type. The electron concentration caused by In implantation and annealing was found to saturate at a value of $3 \times 10^{18} \mathrm{~cm}^{-3}$ for doses larger than $1 \times 10^{14} \mathrm{~cm}^{-2}$. This result is in agreement with investigations of solid solutions of InTe in PbTe. Finally, mesa diodes have been fabricated by standard lithographic procedures. Zero bias resistance area products as high as $0.4 \Omega \mathrm{cm}^{2}$ have been obtained.

\section{References}

[1] KaSAI, I., Hornung, J. and BaArs, J., J. Electronic Mat. 4 (1975) 299 ; J. Appl. Phys. 47 (1976) 3167.

[2] BettinI, M. and Richter, H. J., Surface Science, to be published.

[3] Rosenberg, A. J. and Wald, F., J. Phys. Chem. Solids 26 (1965) 1079.
[4] Averkin, A. A., Kaidanov, V. I. and Mel'nik, R. B., Sov. Phys. Semicond. 5 (1971) 75.

[5] Borovikova, R. P., Efimova, B. A., Kazanskaya, O. A. and Kosolapova, E. F., Inorg. Mat. 12 (1976) 1440. 